\title{
Broadcast Media and Rural Mobilization: Did it help the Ebola Awareness Campaign in Nigeria?
}

\section{Andy Fred Wali*}

Federal University, Wukari, Taraba State, Nigeria

\begin{abstract}
This study investigates broadcast media and rural mobilization and its influence on Ebola awareness campaign in Nigeria. The study adopted a phenomenological ontology and specifically employed focus group and single oneto-one interview approaches to collect data from residents in a single local government in South region of Nigeria. 3 focus group interviews with 19 rural dwellers were conducted, while 8 single one-to-one interviews were conducted on media and health professionals, making it a total of 27 participants. Data were analysed using thematic template and content analysis techniques with NVivo 11 software for data management, thematic weighting and coding. Findings showed that four key themes: Language usage; the misconception of message content; expertise of Journalist and science journalism; and rural media participation influence participants' experiences of broadcast media awareness campaign on Ebola disease in rural communities. But, language and rural media participation strategies were mostly employed by broadcast media professional for Ebola campaign awareness.
\end{abstract}

Keywords: Broadcast media; Rural mobilisation; Ebola awareness campaign; Qualitative focus group approach

\section{Introduction}

Nothing has united Nigerians as the episode of a deadly infectious Ebola Virus Disease (EVD). The venomous tropical disease came into Nigeria following the outbreak in Lagos in July, 2014, by a LiberianAmerican, who came into the country with the virus. More than four persons died because of the outbreak of the disease, leaving a good number quarantined across the country. However, after much careful campaign, health education and unity of purpose Nigeria was certify free from the deadly disease [1]. EVD initially called Ebola Haemorrhagic Fever is a living organism that depends on its host to survive and it first appeared in the Democratic Republic of Congo in 1976 in the neighbourhood of the Ebola River from which the name is derived [2]. Afterwards, the disease remains confined to Africa in the now endemic countries of the DRC, Uganda, Sudan and Gabon, with only one sporadic in Ivory Coast in 1994. Currently, the epidemic has sprang endemically for the first time in West Africa in Guinea, Liberia and Sierra Leone.

Notably, the carriers of this deadly virus are bats, chimpanzee, antelopes, porcupines, rats and swine and communicated to humans through consumption of infected primate (bush meat); whereas its transmission from human to human was through a body touch with person(s) who had the infection [3]. Very notable symptoms begin with very strong weakness in the body, continuous fever, pain in the muscles, sore throat including headache, meanwhile diarrhea, rashes, vomiting are not left out. There is weakness in the kidney and malfunction liver, there is also bleeding both internally and externally which is the advanced stage [4]. Therefore, there is a cogent need for the nation to keep up the continuous health care awareness campaign so as to uphold the permanent conquest over not just Ebola Virus Disease but also any other invading deadly disease(s) such as Kyasanur Forest Disease, O'nyong Nyong Fever, Bolivian Haemorrhagic Fever, Marburg Disease etc., that are apparently new to medicine. The Broadcast media is the most distinguished of the various media of communication. It plays a unique and constructive role in today society in increasing awareness towards issues of communication. The broadcast media promotes the right things as at when due and warns about what is right or wrong. The world according to Lancet is making progress in every steps of life, but we cannot refuse the fact that we all are enclosed directly or indirectly with communal problems and issues that are affects the general public. Broadcast media is an avenue to calculate approximately the realities of life also focusing on every matter and explores the issues of societies openly. Therefore, this study explores ways in which media, given their role in the fight against Ebola will be employed in future as an effective tool in campaigns and mobilization of rural communities during health crisis situations.

Key research questions for this study are:

What media strategy was adopted by broadcast media organizations during the campaign for Ebola eradication? What appropriate medium might be suitable for rural mobilization in future health campaign? How can the broadcast media be effective in their campaigns in rural community during health crisis situations?

\section{Literature Review}

The lens for this study is Democratic Participatory Theory (DPT) McQuail [5] and the theory argues that communication should be horizontal and not vertical. It criticized the dominance of the main mass media by private and public monopolies and encourages the reach and inclusion of inputs by relevant groups in the design and implementation of a development project. Our Justification for choosing the DPT is that it encourages the engagement of local population in development project. Additionally the DPT is understood to have sealed and revived local cultures by promoting the right to information, both global and local, the right to articulate feedback and also the right to use new technology as much as expecting the government to provide fund for trainings and they should also subsidies if there is financial

${ }^{*}$ Corresponding author: Andy Fred Wali, Federal University, Wukari, Taraba State, Nigeria, Tel: +234800000000; E-mail: andim4u@gmail.com

Received November 07, 2017; Accepted June 22, 2018; Published June 29 2018

Citation: Wali AF (2018) Broadcast Media and Rural Mobilization: Did it help the Ebola Awareness Campaign in Nigeria? J Mass Communicat Journalism 8: 378. doi: 10.4172/2165-7912.1000378

Copyright: @ 2018 Wali AF. This is an open-access article distributed under the terms of the Creative Commons Attribution License, which permits unrestricted use, distribution, and reproduction in any medium, provided the original author and source are credited. 
difficulties. Broadcast media (radio and television) helps in creating awareness by informing and advertising a wider range of individual or persons. Asemah the broadcast media is an effective medium of rural mobilization through helping to organize support for governmental program and polices against issues of corruption and terrorism, epidemic outbreak etc. Ikpeze [6] opined that broadcast media has long been used in the promotion of good health practices and in the prevention of various social and health problems In all its diversity, the broadcast media has been identified as constituting a primary source of information through which people learn about the world around them during the outbreak of the Ebola virus disease in Nigeria. The term public communication campaigns tends to shape behaviours toward desirable social outcomes through literature and what experts variously submit to as civic information, public education, public awareness, or public rendezvous campaigns [7]. The ultimate goals of public communication campaigns include healthier individuals, families, and communities. It features only communications through media channels $[8,9]$.

\section{Research Strategy}

This study adopted the qualitative research design to explore perceptions of rural community dwellers, healthcare providers and journalists regarding the impact of broadcast media on rural mobilization for Ebola campaign awareness during the upsurge in a single state in South Nigeria. The study choose the interpretivist paradigm because it would help explore in-depth experiences of rural dwellers on the impact Ebola campaign between 2014-2015 and the social constructivist focus group (FG) approach was specifically chosen for this study [10]. The population of this study was rural dwellers, media and medical professionals in Akwa Ibom State, Nigeria and our accessible population was those in Ikot Abasi metropolis of the state. A purposive sampling technique was employed for recruiting participants and conducting focus group and single interviews. Ikot Abasi Local Government Area is part of Ibibio ethnic nationality with five clans that cover an area of 221 square kilometers and these clans are namely: Ikpa Nnung Assang, Ukpum Ete, Edemaya, Ukpum Okon and Ikpa Ibekwe, respectively.

\section{Recruitment Ethics and Criteria}

30 rural dwellers were initially recruited through a community youth President and a Village Head, but only 19 were happy to participate in the 3 focus group interviews- FG 1 (8participants) FG 2 (7 participants) and FG 3 (4participants). Second a recruitment instrument was distributed to 10 Journalist and 5 Nurses who are known to one of the researcher and of this number only 3 Journalist and 5 Nurses showed interested and were selected [11]. After one week we sent out emails and mobile short message services (SMS) to these Journalist and Nurses proposing tentative dates for the interviews and positive replies were received after 3 days. These Journalists and Nurses were selected based on the following: Journalists who are correspondents and informants and have worked successively in the rural communities of Ikot Abasi for at least five years were because they understood the complexities of mass media and health communication campaigns. Nurses and Midwives who are currently in active service at the government healthcare centre and this decisive factor helped certified the conscription of participants who best reflected the intended population of healthcare providers. This is because these participants were witnesses to Ebola epidemic eruption and campaigns, and residents who are familiar with Ebola EVD outbreak and had been active inhabitants of Ikot Abasi for at least 10 years. FG1 - lasted for 1 hour 3 minutes, FG2 - 1:52 minutes and FG3 - 1:46 minutes and each of the single interviews lasted between 30 mins and 49 mins [12,13]. We had a total of 27 participants in this study as previous studies have opined that 6-12 participants is justified for data saturation but we had 27 participants [11].

\section{Coding and Thematic Analysis}

Thematic template and content analysis techniques were employed for data analysis Gibbs [14], King and Horrocks with NVivo 11 for data management, coding and thematic weighting $[11,15]$. We followed the thematic template analysis process of Braun and Clarke - identify initial themes; review initial themes and Wali and Wright [10], Wali et al. [15], Wali and Nwokah [11] - eliminate repetitive themes with similarity in meaning using percentage of coding strength and then emergence of final themes (Figure 1).

\section{Emerging Thematic Findings and Definitions}

Findings showed that four key themes influenced participants' experiences of the Ebola awareness campaign message in rural communities and they are: (a) Language usage; (b) misconception of message content; (c) expertise of Journalist and science journalism; (4) rural media participation.

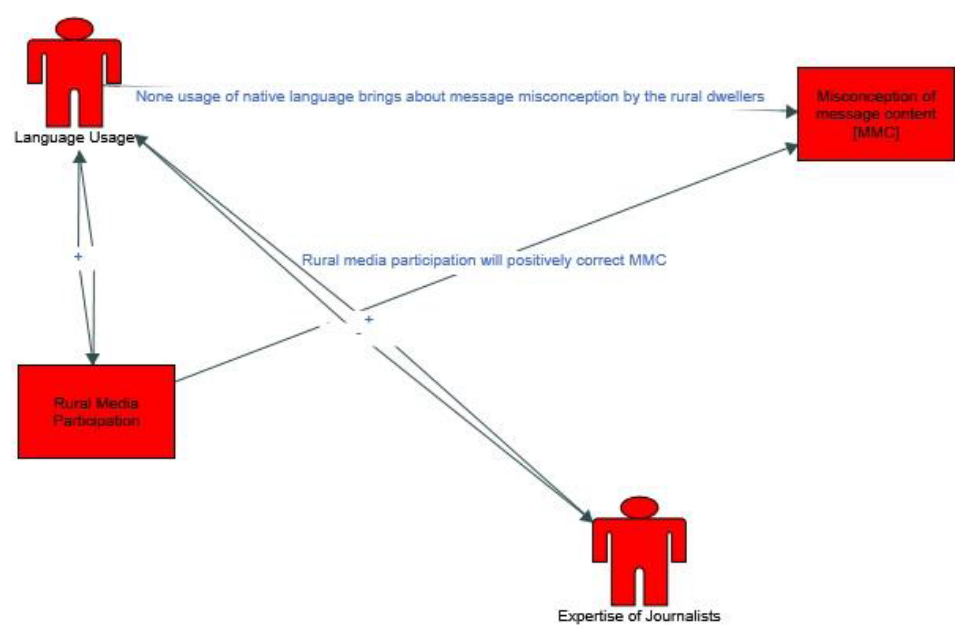

Figure 1: NVivo 11 thematic map showing links between themes. 


\section{Theme 1: Language usage}

This theme refers to the use of selected Nigeria native language in broadcasting Ebola awareness campaign. The implication follows that since most rural dwellers are illiterates using English Language for Ebola campaign message will make no since instead will create misconception about the message. This theme-Language is liked with the theme-misconception of message content [16]

"During the Ebola crisis some stations like AKBC (Both Radio and Television) Atlantic FM 104.5 and Inspiration 105.9FM cast news in local language (Ibibio, Efik)" [Participants in community focus group and interviewee $1 \& 3]$.

"I really do not know what to tell my people again; I first heard we can protect ourselves by chewing bitter cola and bath salt", many of the respondents interviewed admitted they followed the instruction of chewing bitter cola and bathing with salt and these messages were passed on to us with Local language" (Participant in community focus group 2\&3; $4^{\text {th }}$ Nurse interviewee).

\section{Theme 2: Misconception of message content}

This theme suggest that Ebola campaign messages which were broadcasted in English on TV were misconceived by rural dwellers since they do not understand English language and the misconceptions were facilitated by Ebola campaign picture and videos.

"The Ebola campaign pictures and videos we saw on the TV suggest that Ebola kills, this is because we really did not understand the content of the messages but pictures and things" [Participants in Focus group $2 \& 3]$.

"The news and talks about Ebola disease was frightening, as we were even scared of going to market so as not to have body contact with others" (Participant Focus group 1, and $1^{\text {st }}$ Nurse interviewee).

"One of the stations reported these stories like the disease will get to our village this minute and another villager was worried about the many rumors and misconceptions that surrounded the outbreak of the disease, I mean we became confused and cast our hope on God" (Participant in Community Focus group 3).

\section{Theme 3: Expertise of journalist}

"The time allotted for the jingles and news was not sufficient to effectively sensitize the rural target audience on the Ebola virus disease" (Interviewee-Journalist 1 and 2).

"Ebola jingles were designed to dispel these misconceptions and sensitize the public on preventive measures" (Journalist 12 and 3).

\section{Theme 4: Rural media participation}

This theme follows that there was the need for government to establish and robust community based radio station (CRS) in Local Government Area headquarters. This is because the establishment of CRS will disseminate information swiftly to rural dwellers in times of national emergencies.

"I think that an integration of the traditional and modern media especially those which are based in our Local Government Area will be appropriate for rural mobilization and sensitization and will spur our children to aspire to study Journalism" Paraphrased from (Focus group 1 and 3 participants, interviewees 4,5 and 8 ).

"Traditional media system was grossly under-utilized in this Ebola campaign" (Participant in community focus group 1).

\section{Discussion and Contribution}

The study showed that the effective mode of media communication in rural communities is ethnic media and there has been no unanimous scholarly suggestion that both the traditional (ethnic) media and modern media should be used for future mobilization of national health campaigns. But, the mode of communication mode should be determined by the composition of target audience. Also some Radio and Television Stations in the State especially government owned stations cast news in two dominant local language (Ibibio, Efik) which is targeted at information to illiterate rural dwellers. This is because our indigenous languages help in promoting national consciousness and rich communications amongst citizens especially in a multi lingual society like Nigeria. The challenge for the broadcast media in the campaign against the Ebola Virus Disease (EVD) in was the framing of the epidemic of the Ebola virus disease outbreak. This source argues that the mass media force attention to certain issues and they are constantly presenting objects, suggesting what individuals in the mass should think about, know about, have feelings about, The study also reported that negatively framed media content message could be a source of misconception while positively framed media message brings about message acceptance by rural dwellers. Others argue that media frames sources help to communicate messages in a certain direction and allow receivers of information to gain a clear perspective of the subject. However, in the case of this study the broadcast media framing of the EVD campaign awareness was to press home the enormity of the disease to rural audience. Another theme identified which characterized the experiences of participants was rural media participation and follows that the adoption of rural media strategy in the Ebola campaign was poor hence it negatively affected the expected outcome of sensitization efforts of the broadcast media in rural communities. This implies that perhaps the number of casualties recorded in our rural communities during the Ebola outbreak could have be reduced if rural media participation strategy was immediately conceived and implemented through radio and television. These findings follows that the broadcast media can adopt these four themes if they must succeed in effective rural mobilization, sensitization and participation in programs that would impact women in rural areas, just like the outbreak of diseases like Ebola in the future. First this study has contributed to theoretical knowledge by advancing the value of Democratic Participatory Theory of because whilst previous literature has extensively elaborated on this theory in developed economies, our becomes the first to postulate amongst other themes found in this study the inclusion of rural media participation strategy within democratic participatory theory framework in delivering the value of broadcast media in rural communities in Nigeria. This, however, suggest that though the democratic participatory theory might be less emphasized in developed nations, but it's value is still relevant for use in emerging economies like Nigeria where rural dwellers constitute $65 \%$ of the country's population. Second, it has made operational contribution because our study's thematic findings especially language usage and rural media participation strategy have created new window of opportunities for existing media professionals and laggard investors to explore niche media audience in rural areas.

\section{Conclusion and Recommendations}

The effectiveness of media campaigns aimed at mobilizing and sensitizing target audience must consciously be designed with the interest of the audience in mind. To achieve this will require the adoption of strategic communication paradigm. The efficacy of the message is highly among other intervening variables dependent of 
Citation: Wali AF (2018) Broadcast Media and Rural Mobilization: Did it help the Ebola Awareness Campaign in Nigeria? J Mass Communicat Journalism 8: 378. doi: 10.4172/2165-7912.1000378

the medium. That is to say, what could be termed appropriate and useful medium for some audience might not be same for others. The advocacy for the development of the traditional media as a potent communication tool for rural communities cannot be overemphasized. In view of the findings, the following recommendations are suggested that: A special training be given to journalists in the broadcast media, the areas of science journalism and rural reporting. This is to equip them with requisite knowledge on science reporting and to consciously report rural events in a more comprehensible, participatory and development-oriented manner. The broadcast media commits ample airtime to accommodate local contents, that reflect the social and economic realities in the rural setting as well as lofty efforts they are making to better their lots. This will mean the integration of the traditional and modern media for effective communication. Strategic communication paradigm is needed for effective broadcast media campaign against the Ebola Virus Disease in rural areas. This will mean, taking the message against the virus to the rural areas via the means they can easily access and relate with. Efforts be made by government and relevant NGOs towards the establishment of ethnic radio, which will not only serve local people, but also a go between them and the leaders. Relevant stakeholders be engaged by the broadcast media and indeed government to drive development messages and eventually foster sensitization through the lines. They are effective to reaching target audience who might not be reached via the broadcast media. This will foster participation and a sense of ownership of government programs and policies.

\section{References}

1. World Health Organization (2014) Nigeria is now free of ebola virus transmission. Media centre.

2. Martini GA (1980) Spermatogenic transmission of the "Marburg virus". Asian Pacific Journal of Reproduction 4: 83-84.
3. Eichner M, Dowell SF, Firese N (2011) Incubation period of ebola hemorrhagic virus subtype Zaire. Osong Public Health Res Perspect 2: 3-7.

4. Althaus CL (2014) Estimating the reproduction number of Ebola virus (EBOV) during the 2014 outbreak in West Africa. Ambizione grant from the Swiss National Science Foundation (project 136737).

5. McQuail D (1983) Mass communication theory: An introduction. $2^{\text {nd }}$ edn London: Sage publishers.

6. Ikpeze IO (2007) Mass media and promotion of good health practices. Lagos Aderigbe publishers limited. $1^{\text {st }}$ ed. p. 124

7. Weiss JA, Tschirhart M (1994) Public information campaigns as policy instruments. Journal of Policy Analysis and Management 13: 82-119.

8. Dungan-Seaver D (1999) Mass media initiatives and children's issues: An analysis of research and recent experiences relevant to potential philanthropic founders. Electronic version. Paper prepared for the McKnight Foundation.

9. Rogers EM, Storey JD (1987) Communication campaigns. In: Handbook of communication science. Berger C, Chaffee S editors. 817-846, Newbury Park Sage, CA.

10. Wali AF, Wright LT (2016) Customer relationship management and service quality: influences in higher education. Journal of Customer Behaviour 15: 67-79.

11. Wali AF, Nwokah GN (2016) Premium customers' perception of firms' customer relationship management segmentation, identity strategies and their satisfaction. International Journal Markets Business Systems 2: 291-308.

12. Silva EB, Wright D (2005) The Judgement of Taste \& Social Position in Focus Group Research, in Bryman, pp: 241-253.

13. Warr DJ (2005) 'It was fun, but we don't usually talk about these things: analyzing sociable interaction in focus groups'. Qualitative Inquiry 11:200-22.

14. Gibbs A (2008) Focus groups. Social research update.

15. Wali AF, Uduma IA, Wright LT (2016) Customer relationship management (CRM) experiences of Business-to-Business (B2B) marketing firms: A qualitative study. Cogent Business and Management 3: 1-22.

16. Mohanty M, Parhi P (2011) Folk and traditional media: A powerful tool for rura development. Journal of communication 2: 41-47. 